\title{
Penerapan Model Pembelajaran Problem Based Learning untuk Meningkatkan Prestasi Belajar Matematika dan Aktivitas Siswa
}

\author{
Retna Widayanti ${ }^{1 *}$, Khumaeroh Dwi Nur'aini ${ }^{2 * *}$ \\ ${ }^{1}$ SMP YPPK Yoanes XXIII Merauke \\ ${ }^{2}$ Universitas Musamus \\ *) retna2112@ gmail.com \\ **) korespondensi: khumaeroh_fkip@unmus.ac.id
}

\begin{abstract}
Abstrak
Penelitian tindakan kelas ini bertujuan untuk meningkatkan prestasi belajar matematika dan aktivitas siswa melalui pembelajaran Problem Based Learning (PBL). Subjek penelitian adalah 35 siswa kelas 8 SMP di Merauke. Pengumpulan data menggunakan tes hasil belajar dan lembar observasi siswa. Penelitian ini dilakukan dalam 2 siklus. Metode penelitian ini adalah metode statistik deskriptif. Setelah dilakukan analisis data, didapatkan hasil bahwa prestasi belajar dan aktivitas siswa meningkat sesuai indikator pencapaian. Hal ini dapat dilihat dari besarnya ketuntasan hasil belajar matematika siswa pada siklus I sebesar $54,84 \%$ dan pada siklus II sebesar $80 \%$. Hasil belajar pada kedua siklus menunjukkan bahwa ketuntasan klasikal hasil belajar sudah memenuhi indikator yang telah ditetapkan yakni lebih dari atau sama dengan $75 \%$ dari keseluruhan jumlah siswa yang mengikuti tes akhir siklus mengalami ketuntasan belajar. Selain itu, terdapat juga peningkatan aktivitas siswa pada siklus I dan siklus II berturut-turut sebesar $41,93 \%$ dan $87,10 \%$.
\end{abstract}

Kata Kunci: prestasi belajar, aktivitas siswa, problem based

\begin{abstract}
This class action research aims to improve mathematics learning achievement and student activities through Problem Based Learning (PBL) learning. The research subjects were 35 8th grade students of SMP in Merauke. Data collection using test results and student observation sheets. This research was conducted in 2 cycles. This research method is a descriptive statistical method. After analyzing the data, the results show that student achievement and activity increase according to the achievement indicators. This can be seen from the amount of completeness of students' mathematics learning outcomes in the first cycle of $54.84 \%$ and in the second cycle of $80 \%$. Learning outcomes in both cycles indicate that the classical completeness of learning outcomes has met the predetermined indicators that is more than or equal to $75 \%$ of the total number of students who take the final test cycle have mastery learning. In addition, there was also an increase in student activity in the first cycle and second cycle by $41.93 \%$ and $87.10 \%$.
\end{abstract}

Keywords: learning achievement, student activities, problem based learning

\section{Pendahuluan}

Pembelajaran matematika umumnya sering dilakukan dengan langkah-langkah tradisional dimana guru menyampaikan materi pembelajaran, kemudian mengajukan beberapa pertanyaan, dan meminta siswa yang pasif untuk aktif dengan memulai mengerjakan latihan dari buku teks, pelajaran diakhiri dengan pengorganisasian yang baik 
dan metode tersebut diterapkan kembali pada pembelajaran selanjutnya. Kegiatan belajar yang demikian tidaklah selalu buruk. Terkadang ada siswa yang akan lebih mudah mengerti konsep materi yang diajarkan guru melalui soal-soal latihan. Dari soal-soal tersebut, siswa akan memahami cara penggunaan rumus dan aplikasi materi dalam kehidupan realistik yang kemudian siswa akan memahami konsep dasar materi tersebut.

Setiawan (2017) mengemukakan bahwa "Pembelajaran Matematika hendaknya dimulai dengan pengenalan masalah atau mengajukan masalah riil atau nyata, yaitu pembelajaran yang mengaitkan dengan kehidupan sehari-hari siswa, kemudian siswa secara bertahap dibimbing untuk menguasai konsep Matematika dengan melibatkan peran aktif siswa dalam proses pembelajaran". Senada dengan pendapat tersebut, menurut Hebert, dkk (Van de Walle, 2007) membuat materi pelajaran menjadi problematis berarti membuat siswa menjadi ingin tahu atas penyebab suatu hal, menyelidiki soal, mencari penyelesaian, dan menyelesaikan kejanggalan yang ada. Hal ini berarti bahwa kurikulum dan pengajaran harus dimulai dengan soal-soal, dilema-dilema dan pertanyaan-pertanyaan untuk siswa. Lebih lanjut, Van de Walle mengemukakan bahwa persoalan untuk belajar matematika memiliki ciri-ciri sebagai berikut.

1. Soal harus disesuaikan dengan kondisi siswa. Rancangan tugas harus didasarkan pada pemahaman terakhir yang dimiliki siswa agar bisa terlibat dan menyelesaikan soal dan memandang soal sebagai sesuatu yang menantang dan menarik.

2. Soal harus dikaitkan dengan matematika yang akan dipelajari siswa. Dalam menyelesaikan soal atau mengerjakan kegiatan, siswa terutama harus diarahkan untuk memahami matematika yang terkait, sehingga mereka terlibat dalam mengembangkan pemahaman terhadap idde-ide matematika.

3. Jawaban dan metode penyelesaian soal memerlukan justifikasi dan penjelasan. Siswa harus memahami bahwa tanggung jawab untuk menentukan apakah jawabanya benar dan mengapa benar adalah pada diri mereka. Pemahaman harus merupakan bagian utuh dari penyelesaian mereka.

Berdasarkan wawancara dengan guru mata pelajaran matematika kelas 8 di salah satu SMP di Merauke, diperoleh informasi bahwa melalui latihan soal, siswa akan lebih mudah memahami konsep materi aritmatika. Selain itu, ketidakkondusifan lingkungan kelas akan memberikan kesempatan siswa memperbincangkan topik selain materi pelajaran yang sedang dipelajari, kondisi kelas yang gaduh membuat pembelajaran tidak efektif dan efisien sehingga proses pembelajaran matematika di kelas menjadi terhambat. Hal-hal 
tersebut berdampak terhadap ketidakoptimalan hasil belajar matematika. Partiipasi aktif dari siswa dapat mendukung terjadinya proses pembelajaran khususnya pembelajaran matematika akan lebih efektif dan bermakna. Oleh karena itu, guru perlu memfasilitasi siswa dengan metode pembelajaran yang tepat sehingga siswa terlibat secara aktif dalam pembelajaran. Pembelajaran yang mengutamakan penguasaan kompetensi harus berpusat pada siswa (students centered), memberikan pembelajaran dan pengalaman belajar yang relevan dan sesuai dengan kehidupan sehari-hari dan mengembangkan mental yang kuat dan kaya pada siswa. Kegiatan pembelajaran harus mampu mengeksplorasi kompetensi siswa, baik dalam ranah kognitif, afektif, maupun psikomotorik. Strategi pembelajaran yang berpusat pada siswa dan penciptaan suasana yang menyenangkan sangat diperlukan untuk meningkatkan hasil belajar siswa. Dalam mata pelajaran matematika, guru dapat mengaplikasikan pembelajaran berbasis masalah (Problem Based Learning) dalam meningkatkan kemampuan pemahaman matematis siswa.

Pembelajaran berbasis masalah adalah suatu proses pembelajaran yang dimulai dengan ide-ide dan membangun pemahaman di atas ide-ide yang telah dimiliki siswa. Mengajar dengan model ini merupakan proses yang memerlukan kepercayaan kepada siswa, yaitu kepercayaan bahwa semua siswa dapat membuat ide yang bermakna tentang matematika sehingga nantinya siswa akan lebih bersemangat mempelajari matematika. Duch (2001) menyatakan bahwa Problem Based Learning merupakan pendekatan pembelajaran yang mempunyai ciri menggunakan masalah nyata sebagai konteks bagi siswa untuk belajar berpikir kritis, keterampilan pemecahan masalah, dan memperoleh pengetahuan mengenai esensi materi pembelajaran. Sebagaimana pendapat Haylock \& Tangata (Palobo \& Nur'aini, 2018) yang menyatakan bahwa hasil yang paling positif dari pengalaman sukses memecahkan masalah untuk murid dari segala usia adalah rasa puas yang terjadi ketika masalah tersebut akhirnya dapat diselesaikan, yang memberikan dorongan peningkatan kepercayaan diri peserta didik dan memberikan kontribusi untuk sikap positif. Walaupun siswa lebih banyak belajar sendiri, peran guru juga sangat penting untuk memantau aktivitas serta memfasilitasi proses belajar dan merangsang siswa untuk berfikir kritis dalam memecahkan masalah yang ada. Tugas guru mengarahkan siswa untuk bertanya, membuktikan asumsi, dan mendengarkan persfektif yang berbeda diantara mereka. 
Sumartini (2015) mengemukakan bahwa karakteristik dari pembelajaran berbasis masalah (problem based learning) adalah (1) berdasarkan pada masalah, masalah tersebut membantu pengembangan kemampuan itu sendiri bukan menguji kemampuan, (2) masalahnya benar-benar ill structured, tidak setuju pada sebuah solusi, dan ketika informasi baru muncul dalam proses, presepsi akan masalah dan solusi pun dapat berubah, (3) guru bertindak sebagai pelatih dan fasilitator, siswa menyelesaikan masalahnya sendiri, (4) tidak ada suatu rumus bagi siswa untuk menyelesaikan masalah, siswa hanya diberikan petunjuk bagaimana mendekati masalah, dan (5) orisinalitas dan penampilan

Oleh karena itu, maka rumusan dan tujuan penelitian ini adalah apakah pembelajaran dengen pendekatan Problem Based Learning dapat meningkatkan prestasi belajar matematika dan aktivitas siswa kelas 8 SMP Di Merauke.

\section{Metode Penelitian}

Penelitian ini merupakan penelitian tindakan kelas yang dibagi menjadi empat tahap yaitu tahap perencanaan, pelaksanaan, pengamatan atau observasi, serta refleksi. menggunakan desain Kemmis \& Mc Taggart (Arikunto, 2014: 137). Penelitian ini dilaksanakan pada semester ganjil tahun ajaran 2019/2020 di YPPK YOANES XXIII Merauke. Penelitian ini merupakan kolaborasi antara Guru Mata Pelajaran dan Dosen Pelaksana dimana seluruh instrumen dan materi ajar pada penelitian dirancang bersama secara konseptual berdasarkan pengalaman dan kondisi yang ada. Selanjutnya pada tahap pelaksanaan penelitian di kelas juga dilakukan secara bersama-sama. Kedua tahapan tersebut disertai tahap observasi dan refleksi agar diperoleh informasi mengenai kekurangan dan aktivitas siswa selama penelitian berlangsung sehingga diperoleh hasil pembelajaran yang sesuai dengan tujuan penlitian.

Subjek dalam penelitian ini adalah 35 siswa kelas VIII.3. Penelitian in menggunakan beberapa instrumen, antara lain adalah lembar tes akhir siklus untuk prestasi belajar dan lembar observasi aktivitas siswa. Dalam mengukur aktivitas siswa selama pembelajaran antara lain, peneliti memperhatikan beberapa aspek berikut. : 1) Siswa mengucapkan salam. 2) Siswa memperhatikan dengan seksama ketika guru menjelaskan. 3) Siswa terlibat dalam kegiatan diskusi (saling menerima dan memberi informasi menggunakan kartu yang dimilikinya). 4) Siswa berani mengemukakan pendapat saat guru memberikan pertanyaan. 5) Saat tidak memahami persoalan, siswa berani untuk bertanya. 6) Siswa 
berani mempresentasikan hasil diskusi. 7) Siswa menunjukan sikap bertanggung jawab yang dapat terlihat dari terselesaikannya tugas yang diberikan oleh guru. 8) Siswa menyimpulkan materi yang telah dipelajari.

Skala Likert dengan 5 kategori digunakan dalam penelitian ini. Diadopsi dari (Sudjiono, 2011: 329), berikut interval dan kategori skor aktivitas siswa dan guru.

Tabel 1. Pedoman Konversi Penilaian

\begin{tabular}{|c|c|}
\hline Rentang Nilai & Kategori \\
\hline $\mathrm{Mi}+1,5 \mathrm{Sdi}<\mathrm{X}$ & Sangat Tinggi \\
$\mathrm{Mi}+0,5 \mathrm{Sdi}<\mathrm{X} \leq \mathrm{Mi}+1,5 \mathrm{SDi}$ & Tinggi \\
$\mathrm{Mi}-0,5 \mathrm{Sdi}<\mathrm{X} \leq \mathrm{Mi}-0,5 \mathrm{SDi}$ & Sedang \\
$\mathrm{Mi}-0,5 \mathrm{Sdi}<\mathrm{X} \leq \mathrm{Mi}-0,5 \mathrm{SDi}$ & Rendah \\
$\mathrm{X} \leq \mathrm{Mi}-1,5 \mathrm{Sdi}$ & Sangat Rendah \\
\hline
\end{tabular}

Perhitungan standar deviasi ideal (SDi) dan mean ideal (Mi) adalah:

$$
\begin{aligned}
M i & =\frac{1}{2}(\text { Skor Maksimum }+ \text { Skor Minimum }) \\
S D i & =\frac{1}{2}(\text { Skor Maksimum }- \text { Skor Minimum })
\end{aligned}
$$

Langkah-langkah yang digunakan untuk mengetahui ketuntasan klasikal aktivitas siswa yaitu: menentukan skor aktivitas siswa dalam pembelajaran, menentukan kategori skor aktivitas, kemudian menghitung persentase aktivitas siswa dikatakan tuntas apabila aktivitas berada pada kategori tinggi dan sangat tinggi (mencapai 75\%). Indikator keberhasilan dalam penelitian ini adalah adanya peningkatan hasil belajar matematika siswa yang mencapai Kriteria Ketuntasan Minimal (KKM) 73 dengan ketuntasan klasikal minimal 75\% siswa mencapai nilai KKM yang ditetapkan. Selain itu, meningkatnya aktivitas aktivitas siswa pada kategori tinggi dan sangat tinggi yang mencapai indikator keberhasilan minimal $75 \%$.

\section{Hasil dan Pembahasan}

Penelitian ini bertujuan untuk meningkatkan prestasi belajar matematika dan aktivitas siswa SMP YPPK Yoanes XXIII Merauke pada materi Barisan dan Deret dengan menggunakan model pembelajaran Problem Based Learning. Penelitian tindakan pada siklus I terdiri atas empat tahapan yaitu: perencanaan, pelaksanaan, pengamatan, dan refleksi. Satu siklus dilakukan dengan 4 kali pertemuan yakni 3 pertemuan untuk pembelajaran dan 1 pertemuan untuk tes akhir siklus.

Hasil pengamatan terhadap pada pelaksanaan tindakan siklus I dideskripsikan sebagai berikut: 
1) Data Hasil Belajar Siswa

31 siswa mengikuti tes hasil belajar pada siklus I pada hari Senin, 24 Agustus 2019 di kelas VIII.3. Materi soal tes awal yang diberikan adalah materi yang telah dipelajari pada siklus I. Pada tes ini subjek diberikan 3 soal uraian.

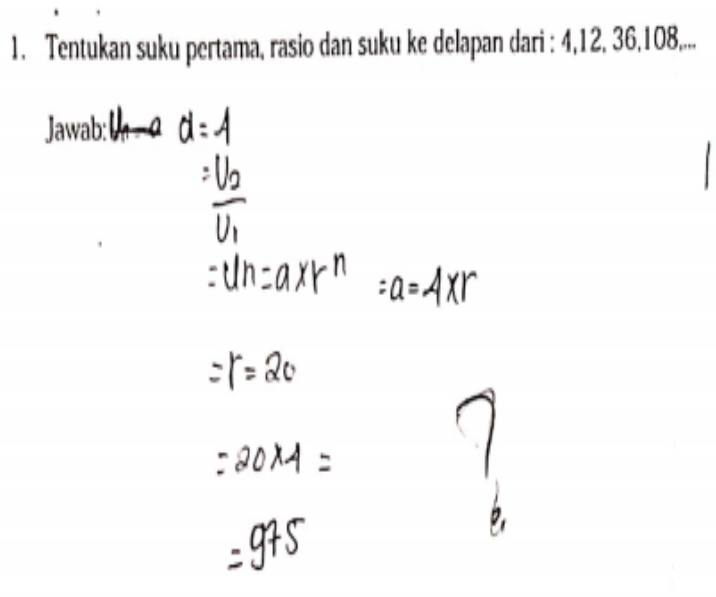

Gambar 1a. Contoh hasil tes siswa yang salah memahami konsep Baris dan Deret

Tentukan suku pertama, rasio dan suku ke delapan dari : 4,12,36,108,

$$
\begin{aligned}
& \text { Jawab: Dik: } a: 4 \quad r: \frac{12}{4} \cdot 3 \\
& \text { Dit: sure kp-o } \\
& \text { kuwusfesaican: Un: } a \times r^{n-1} \\
& \text { Puyplesaion: Un } \cdot a \times r_{n-1}^{n-1} \\
& U_{0}=4 \times 3^{8-1} \\
& \text { - } 4 x+20 \\
& \text { SEEC } \\
& : 4 \times 2187 \\
& .8748
\end{aligned}
$$

Gambar 1b. Contoh hasil tes siswa yang memahami konsep Baris dan Deret dengan baik

Dari gambar di atas terlihat perbedaan yang antara siswa yang telah memahami konsep Materi Barisan dan Deret dengan benar dan siswa yang belum memahami konsep sepenuhnya. Berikut gambaran data hasil pelaksanaan tes siklus I:

Tabel 2. Statistik Deskriptif Hasil Tes Akhir Siklus I

\begin{tabular}{lc}
\hline Deskripsi & Nilai \\
\hline Subjek & 31 \\
\hline Skor Tertinggi Siswa & 100 \\
\hline Skor Terendah Siswa & 10 \\
\hline Skor Rata-Rata Siswa & 63,39 \\
\hline
\end{tabular}

Berikut data hasil belajar matematika kompetensi pengetahuan pada tahap siklus I.

Tabel 3. Ketuntasan Klasikal Prestasi Belajar Matematika Siklus I

\begin{tabular}{llcc}
\hline Nilai & Kategori & Frekuensi & Persentase (\%) \\
\hline$\geq 73$ & Tuntas & 17 & 54,84 \\
\hline$<73$ & Tidak Tuntas & 14 & 45,16 \\
\hline Jumlah & 31 & 100
\end{tabular}


Dari uraian hasil belajar yang telah dipaparkan pada Tabel 2, menunjukkan skor ratarata siswa pada siklus I adalah sebesar 63,39 dan persentase ketuntasan belajar kompetensi pengetahuan sebesar 54,84\%. Dapat ditarik kesimpulan bahwa hasil dari tes akhir siklus I belum mencapai ketuntasan kelas yakni minimal $75 \%$.

\section{2) Data Aktivitas Siswa}

Pada penelitian ini, aktivitas siswa. Aspek aktivitas siswa yang dinilai terdiri atas 8 aspek dengan skor tertinggi dan skor terendah untuk tiap aspek adalah 40 dan 8 . Berdasarkan pengamatan aktivitas siswa pada siklus I diperoleh hasil sebagai berikut.

Tabel 4. Interval dan Kategori Aktivitas Siswa Siklus I

\begin{tabular}{llc}
\hline Rentang Nilai & Kategori & Persentase $(\%)$ \\
\hline $32<\mathrm{X}$ & Sangat Tinggi & 3,23 \\
$26,67<\mathrm{X} \leq 32$ & Tinggi & 38,70 \\
$21,43<\mathrm{X} \leq 26,67$ & Sedang & 32,26 \\
$16.01<\mathrm{X} \leq 21,43$ & Rendah & 22,58 \\
$\mathrm{X} \leq 16,01$ & Sangat Rendah & 3,23 \\
\hline
\end{tabular}

Pada Tabel 4 persentase aktivitas siswa pada kategori tinggi atau sangat tinggi belum memenuhi indikator yang diinginkan, yaitu minimal $75 \%$ dari siswa berada pada kategori tinggi atau sangat tinggi.

Hasil dari pelaksanaan pembelajaran pada siklus I belum mencapai target yang diharapkan. Di awal pertemuan peneliti masih belum bisa menguasai kelas. Hal ini dapat terlihat dari kondisi kelas yang tidak kondusif, tidak idealnya banyak siswa dalam suatu kelompok, kegaduhan terjadi di kelas, banyak siswa yang bermain dan berdiskusi tentang hal di luar materi pembelajaran, sebagian siswa juga masih tidak berani dan tidak percaya diri untuk bertanya ataupun mengemukakan pendapatnya. Kekurangan pada siklus I berasal dari subjek dan juga peneliti ini dapat terlihat dari beberapa permasalahan yang muncul. Dengan demikian, dibutuhkan perbaikan yang harus diperhatikan agar pada hasil siklus II sesuai dengan apa yang ditargetkan. Hal tersebut antara lain sebagai berikut adalah peneliti perlu lebih tegas kepada siswa dalam mengelola kelas, peneliti perlu lebih memonitor siswa pada saat berdiskusi, peneliti perlu memotivasi siswa agar percaya diri untuk mengemukakan pendapat maupun bertanya.

Berdasarkan hasil refleksi di atas, Siklus II dilaksanakan dengan tahapan yang sama seperti pada Siklus I. Pada Siklus II Materi yang dipelajari adalah Sistem Koordinat Kartesius. Pada tahap perencanaan peneliti menyiapkan silabus, RPP, lembar observasi aktivitas siswa, dan tes akhir. Perencanaan yang disusun berdasarkan dari refleksi siklus I. 
30 siswa mengikuti test hasil belajar pada siklus II dilakukan hari senin, 7 September 2019 di kelas VIII.3 Statistik. Materi yang telah dipelajari pada siklus II menjadi soal tes awal yang diberika. Pada tes ini peneliti memberikan 2 soal uraian. Secara lebih rinci, berikut paparan hasil belajar matematika setelah menggunakan model pembelajaran berbasis masalah.

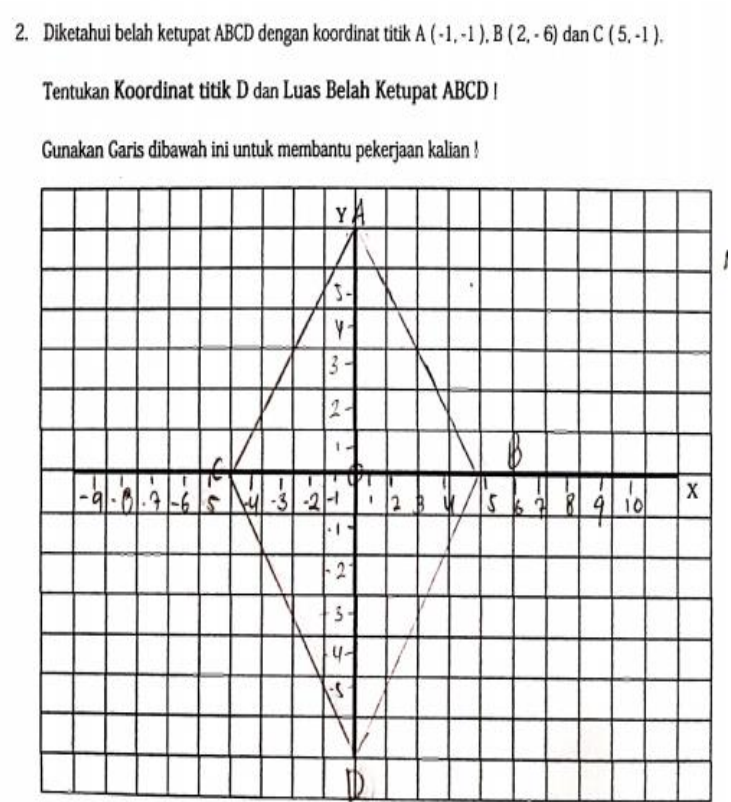

Gambar 2a. Contoh hasil tes siswa yang salah memahami konsep Koordinat kartesius

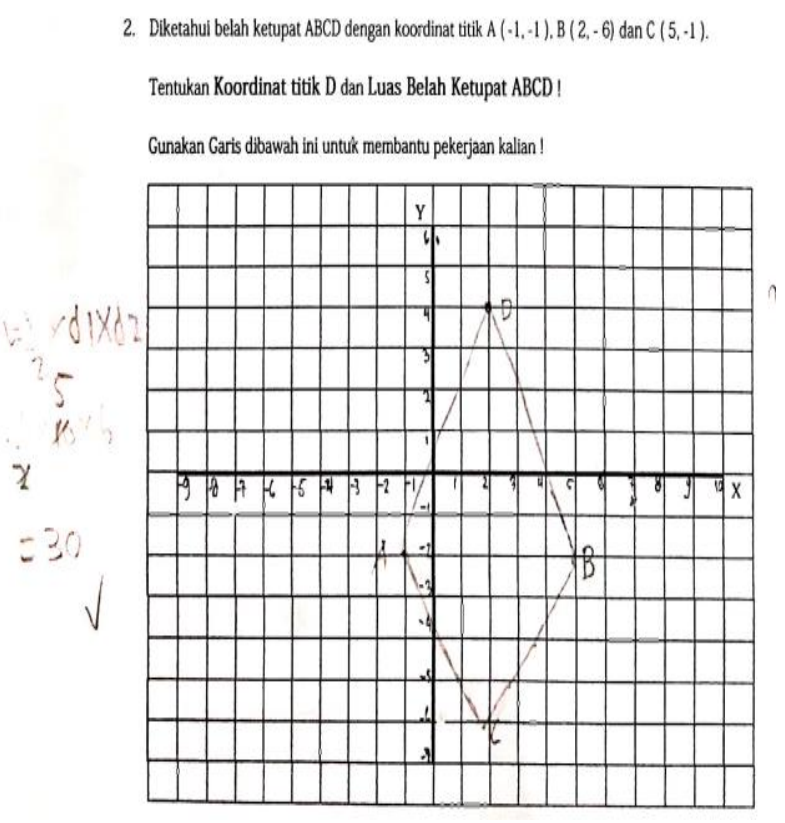

Gambar 2b. Contoh hasil tes siswa yang memahami konsep Koordinat kartesius dengan baik

1) Hasil Belajar Kompetensi Pengetahuan Siklus II

Berikut hasil belajar matematika subjek penelitian.

Tabel 5. Statistik Deskriptif Hasil Tes Akhir Siklus II

\begin{tabular}{lc}
\hline Deskripsi & Nilai \\
\hline Subjek & 30 \\
\hline Skor Maksimal & 100 \\
\hline Skor Minimal & 0 \\
\hline Skor Tertinggi Siswa & 100 \\
\hline Skor Terendah Siswa & 30 \\
\hline Skor Rata-Rata Siswa & 77,37
\end{tabular}


Data hasil belajar matematika kompetensi pengetahuan pada tahap siklus II dapat dilihat pada Tabel 6 berikut.

Tabel 6. Ketuntasan Klasikal Tes Akhir Siklus II

\begin{tabular}{cccc}
\hline Nilai & Kategori & Frekuensi & Persentase (\%) \\
\hline$\geq 73$ & Tuntas & 24 & 80 \\
\hline$<73$ & Tidak Tuntas & 6 & 20 \\
\hline & Jumlah & 30 & 100
\end{tabular}

Dari uraian hasil belajar yang telah dipaparkan pada Tabel 5 dan Tabel 6, diketahui skor rata-rata siswa sebesar 77,37 dan persentase ketuntasan belajar kompetensi pengetahuan $80 \%$. Sehingga dapat disimpulkan bahwa hasil dari tes siklus II mencapai ketuntasan di atas $75 \%$.

\section{2) Data Aktivitas Siswa}

Aspek aktivitas siswa yang dinilai terdiri atas 8 aspek dengan skor tertinggi dan skor terendah untuk tiap aspek adalah 40 dan 8 . Hasil dari observasi aktivitas siswa pada siklus II disajikan dalam tabel berikut.

Tabel 7. Interval dan Kategori Aktivitas Siswa Siklus II

\begin{tabular}{|c|c|c|}
\hline Rentang Nilai & Kategori & Persentase (\%) \\
\hline $32<X$ & Sangat Tinggi & 22,58 \\
\hline $26,67<X \leq 32$ & Tinggi & 64,52 \\
\hline $21,43<X \leq 26,67$ & Sedang & 12,90 \\
\hline $16.01<X \leq 21,43$ & Rendah & 0 \\
\hline $\mathrm{X} \leq 16,01$ & Sangat Rendah & 0 \\
\hline Jumlah & & 100 \\
\hline
\end{tabular}

Berdasarkan Tabel 7, terlihat bahwa hasil analisis data aktivitas siswa pada siklus II untuk kategori tinggi dan sangat tinggi sudah melebihi $75 \%$.

Pembelajaran dengan menggunakan model pembelajaran berbasis masalah dilakukan dalam dua siklus. Masing-masing siklus terdiri dari empat pertemuan yang terdiri dari tiga kali pembelajaran dan 1 kali pertemuan untuk Tes Akhir Siklus. Dalam pembelajaran dengan menggunakan model pembelajaran berbasis masalah, proses pembelajarannya bukan hanya sekedar transfer ilmu dari guru kepada siswa, namun merupakan suatu proses bagaimana guru memberikan kesempatan kepada siswa untuk melihat, memikirkan dan memahami materi yang diberikan. Berdasarkan wawancara terhadap guru mata pelajaran 
matematika kelas VIII.3, diperoleh keterangan bahwa siswa dikelas tersebut sangatlah aktif, akan tetapi saat memahami konsep materi siswa memerlukan waktu yang cukup lama. Selain itu, siswa akan lebih cepat memahami materi jika diberi latihan soal terlebih dahulu.

Dari data perbandingan aktivitas belajar matematika menunjukkan peningkatan presentase aktivitas belajar matematika melalui pendekatan berbasis masalah dari siklus I ke siklus II. Terbukti dari hasil penelitian di Kelas VIII.3 Statistik SMP YPPK Yoanes XXIII Merauke setelah diterapkan model pembelajaran PBL, hasil tes siswa mengalami peningkatan dari $54,83 \%$ pada siklus I menjadi $80 \%$ pada siklus II. Dengan kata lain, peningkatan persentase aktivitas pembelajaran siswa sebesar 25,17\%. Selain itu, pada siklus II terjadi peningkatan aktivitas siswa pada kategori tinggi dan sangat tinggi menjadi $87,10 \%$ dari yang sebelumnya 41,93\% pada siklus I. Model Pembelajaran PBL melibatkan siswa secara aktif dalam pembelajaran, sehingga kegiatan belajar mengajar yang dilakukan lebih interaktif dan siswa tidak merasa bosan karena hanya menyimak materi yang disampaikan oleh guru.

Setelah dilakukan perhitungan, hasil belajar subjek di siklus I masih terkategori rendah. Diperoleh nilai rata-rata 63,39 untuk hasil tes akhir siklus. Masih kurang dari $75 \%$ siswa mencapai nilai KKM yaitu 73. Hal ini disebabkan karena proses pembelajaran yang dilakukan masih belum optimal. Banyak kekurangan yang terjadi pada siklus ini, antara lain kurangnya pengawasan dan ketegasan peneliti kepada siswa dalam mengelola kelas sehingga saat berdiskusi siswa membicarakan hal lain di luar pembelajaran dan tidak memperhatikan ketika peneliti menjelaskan materi secara garis besar di depan kelas. Selain itu, pembagian anggota kelompok yang terlalu banyak yakni 6 orang, menyebabkan proses diskusi menjadi lebih lama dan siswa lebih banyak mengobrol dengan teman kelompoknya. Kurangnya motivasi terhadap siswa menyebabkan saat berdiskusi siswa masih belum percaya diri dan ragu untuk mengemukakan gagasannya atau untuk bertanya.

Untuk menanggulangi kekurangan yang terjadi pada siklus I, maka di siklus II dilakukan beberapa perbaikan agar target tercapai. Peneliti membagi kelompok siswa dalam jumlah yang lebih sedikit yaitu menjadi 3-4 orang per kelompok. Selanjutnya, peneliti memonitor aktivitas siswa pada saat berdiskusi, lalu memotivasi agar siswa lebih berani untuk mengungkapkan gagasan ide dan bertanya. Berdasarkan hasil tes akhir pada siklus II, siswa mengalami peningkatan sebesar $25,17 \%$ dari $54,83 \%$ pada siklus I menjadi $80 \%$ pada siklus II. Setelah memperbaiki kekurangan pada siklus I, siswa menunjukkan 
perubahan positif pada siklus II. Terlihat siswa lebih banyak berbagi dan berdiskusi sesama siswa selama berlangsungnya kegiatan belajar mengajar.

Hasil observasi pada penelitian ini menunjukkan aktivitas belajar siswa mengalami peningkatan dari $41,93 \%$ pada siklus I menjadi $87,10 \%$ pada siklus II. Atau dapats dikatakan bahwa peningkatan aktivitas belajar yang terjadi sebesar 45,17\%. Dengan menggunakan model pembelajaran berbasis masalah siswa menjadi lebih cepat menguasai dan memahami materi yang diberikan, karena memperoleh informasi bukan hanya dari guru melainkan juga dari siswa lainnya selama diskusi dan dari buku sehingga siswa dapat semakin memperdalam pengetahuan yang dimilikinya dengan menggunakan lembar kerja yang diberikan.

Pembelajaran berbasis masalah dapat memungkinkan siswa untuk menjadi bagian dari proses pembelajaran dimana siswa belajar mandiri. Hal ini sejalan dengan pendapat Chakrabarty dan Mohamed (2013) bahwa Problem Based Learning adalah belajar yang berpusat pada siswa di mana ia menekankan proses belajar pada siswa sendiri dengan solusi dan guru bertindak sebagai fasilitator. Siswa bekerja dalam kelompok kecil dan situasi berhubungan dengan kehidupan real. Aktifnya siswa dalam pembelajaran menyebabkan aktivitas siswa semakin meningkat, siswa lebih bersemangat dan antusias saat mengikuti pembelajaran. Seperti yang dikemukakan oleh Rahmadani \& Anugraheni (2017) bahwa "model pembelajaran ini dapat meningkatkan aktivitas matematika siswa". Selain itu, model ini dapat menghemat waktu karena guru tidak harus menjelaskan dan mengajarkan satu persatu tentang materi yang terkait. Berdasarkan pada tes yang dilaksanakan, dengan menggunakan model pembelajaran Problem based Learning dapat meningkatkan hasil belajar matematika dan aktivitas siswa. Hal ini sesuai dengan penelitian yang dilaksanakan oleh Novika (2014) yang menunjukkan bahwa terdapat peningkatan hasil belajar matematika siswa pada setiap siklusnya.

Pembahasan yang diuraikan di atas menunjukkan bahwa proses pembelajaran sudah terlaksana dengan baik. Hal tersebut dapat dilihat dari tercapainya tujuan pembelajaran yaitu adanya peningkatan hasil belajar matematika siswa yang mencapai Kriteria Ketuntasan Minimal (KKM) 73. Adapun ketuntasan klasikal tercapai jika minimal 75\% siswa mencapai nilai KKM yang ditetapkan. Selain itu, terdapat peningkatan aktivitas proses pembelajaran siswa pada kategori tinggi atau sangat tinggi yang mencapai indikator keberhasilan minimal $75 \%$. 


\section{Simpulan dan Saran}

Berdasarkan hasil penelitian dan pembahasan, diperoleh beberapa kesimpulan bahwa penggunaan model pembelajaran Problem Based Learning (PBL) dapat meningkatkan prestasi belajar matematika dan aktivitas siswa dalam pembelajaran. Kesimpulan tersebut didasarkan pada: Meningkatnya prestasi belajar yang sebelumnya hanya 54,84\% pada siklus I kemudian menjadi $80 \%$ pada siklus II. Selain itu, adanya peningkatan aktivitas siswa yaitu $41,93 \%$ pada siklus I menjadi $87,10 \%$ pada siklus II yang termasuk dalam kategori tinggi dan sangat tinggi.

Berdasarkan hasil penelitian, guru disarankan untuk menggaplikasikan model pembelajaran yang sesuai dengan kondisi siswa sehingga siswa lebih mudah memahami materi dan belajar lebih aktif dalam bekerja sama. Serta meningkatkan rasa tanggung jawab dalam melaksanakan tugas.

\section{Referensi}

Arikunto, Suharsimi. (2014). Prosedur penelitian suatu pendekatan praktik (Cetakan Kelima belas). Jakarta: Rineka Cipta.

Chakrabarty, S., \& Mohamed, N. S. (2013). Problem Based Learning: Cultural Diverse Students' Engagement, Learning and Contextualized Problem Solving in A Mathematics Class. WCIK EJournal of Integration Knowledge, 2289-5973

Duch, B.J., Groh, S.E., dan Allen, D.E. (2001). The Power of Problem-Based Learning. Virginia, Amerika: Stylus Publishing

Novika, Tendy A. (2014). Meningkatkan Aktivitas Dan Hasil Belajar Matematika Dengan Strategi Pembelajaran Berbasis Masalah (Problem Based Learning) Pada Pokok Bahasan Segitiga Dan Segiempat Di Kelas VII SMP N 5 Kota Bengkulu. Skripsi S1 Program Studi Pendidikan Matematika, Jurusan Matematika dan Ilmu Pengetahuan Alam, Fakultas Keguruan dan Ilmu Pendidikan, Universitas Bengkulu

Palobo, M \& Nur'aini, K. D (2018). Pengembangan Perangkat Pembelajaran Berbasis Problem Based Learning Berorientasi pada Peningkatan Kemampuan Penalaran dan Sikap Siswa Terhadap Matematika. Jurnal Magistra, Vol 5 No.2 Januari 2018: 15-29

Rahmadani \& Anugraheni. (2017). Peningkatan Aktivitas Belajar Matematika Melalui Pendektan Problem Based Learning Bagi Siswa Kelas 4 SD. Scholaria: Jurnal Pendidikan dan Kebudayaan, Vol 7 No 3, September 2017: 241-250

Setiawan, Hery. (2017). Pembelajaran Matematika Model PBL (Problem Based Learning) Pada Mata Pelajaran Matematika Materi Luas Bidang Pada Siswa Kelas III SD. Junal INOVASI, Volume XIX, Nomor 1. Hal. 8-17

Sudjiono, A. 2011. Pengantar Evaluasi Pendidikan. Jakarta: Raja Grarindo Persada.

Sumartini, Tina Sri. (2015). Peningkatan Kemampuan Penalaran Matematis Siswa Melalui Pembelajaran Berbasis Masalah. Jurnal Pendidikan Matematika. Volume 5, Nomor 1.

Van de Walle, John A .2007. Pengembangan Pengajaran Matematika Sekolah Dasar dan Menengah. Jakarta: Erlangga 